\title{
The effect of dexamethasone on body and organ growth of normal and IGF-II-transgenic mice
}

\author{
R Rooman, J-G Koster, R Bloemen, $\mathbf{R}$ Gresnigt and \\ S C van Buul-Offers
}

Department of Pediatrics, Wilhelmina Children's Hospital, Utrecht University, The Netherlands
(Requests for offprints should be addressed to S van Buul-Offers, Department of Pediatric Endocrinology, Huispost KC 030630, P O Box 85090,
3508 AB Utrecht, The Netherlands; Email: S.vanBuul@wkz.azu.nl)
(R Rooman is now at Department of Pediatrics, Antwerp University Hospital, Wilrijkstraat 10, B-2650 EdegemB-2650 Edegem, Belgium)

\begin{abstract}
The physiological role of IGF-II remains unclear but there is evidence for a role in postnatal growth, the growth of the thymus and bone homeostasis. Glucocorticoids have many effects that are opposite to the effects of IGF-II such as growth retardation, osteoporosis and thymic involution. We therefore wondered whether IGF-II overexpression in transgenic mice might counteract some of the growth inhibitory effects of the glucocorticoid, dexamethasone (DXM).

In a dose-finding study in normal mice, $20 \mu \mathrm{g}$ DXM/ day caused a significant growth delay. The various organs had a different susceptibility to the growth inhibitory effects of DXM. Most affected were thymus and spleen, followed by liver, skeletal muscle and lumbar vertebrae. The weights of the kidney, tibia, and humerus were not significantly diminished.

In a second experiment, the effects of DXM in normal and IGF-II-transgenic animals were compared. The IGF-II serum levels in the transgenic animals were more
\end{abstract}

than 40-fold increased compared with control mice and were decreased by $35 \%$ in the DXM-treated group. IGF-I serum levels were identical in both mouse strains and rose slightly after DXM administration in controls. Transgenic mice had higher levels of IGF binding protein species of apparent molecular masses of $41.5 \mathrm{kDa}, 30 \mathrm{kDa}$, and $26.5 \mathrm{kDa}$. DXM reduced the $24 \mathrm{kDa}$ band in both mice strains. In addition it reduced the bands at $38.5 \mathrm{kDa}$ and $26.5 \mathrm{kDa}$ but only in the transgenic animals.

The effect of DXM on body growth was similar in normal and IGF-II-transgenic mice. The weight reduction of the various organs caused by DXM was similar in both types of mice except for the skeleton. The weight of the tibia and the humerus were significantly higher in the DXM-treated transgenic mice.

In conclusion, we speculate that overexpression of IGF-II in mice partially protects bone from the osteopenic effects of glucocorticoids.

Journal of Endocrinology (1999) 163, 543-552

\section{Introduction}

The insulin-like growth factor (IGF)-I is an important regulator of growth. The physiological role of the structurally related peptide IGF-II, however, remains unclear (Gluckman \& Ambler 1993, van Buul-Offers 1996, Wolf et al. 1998).

Studies on the role of IGF-II in postnatal growth have given conflicting results. In hypophysectomized rats IGF-II administration promotes growth although less well than IGF-I (Schoenle et al. 1985, Shaar et al. 1989, Conlon et al. 1995). Similar results were obtained in Pit-1deficient Snell dwarf mice (van Buul-Offers et al. 1988, 1994). In contrast, IGF-II was ineffective when administered to hypophysectomized neonatal rats (Glasscock et al. 1992), and treatment of neonatal rats with IGF-II antibodies did not change body weight (Robinson et al. 1993). Furthermore, overexpression of IGF-II in transgenic normal and dwarf mice did not affect overall body growth (Rogler et al. 1994, Ward et al. 1994, van Buul-Offers et al. 1995, Wolf et al. 1995) and mice bearing IGF-IIproducing tumors did not show increased body growth (Wilson et al. 1987, Ren-Qiu et al. 1993).

There are some indications for a role of IGF-II in the thymus. IGF-II is present in the thymus (Geenen 1993) and transgenic overexpression of IGF-II mRNA and protein in the medulla of the thymus induced thymic overgrowth (van Buul-Offers et al. 1995, Van Der Ven et al. 1997).

IGF-II may also be a regulator of bone homeostasis. IGF-II is identical to skeletal growth factor (Mohan et al. 1988) and is present in large quantities in bone (Frolik et al. 1988). IGF-II/skeletal growth factor is produced by and is mitogenic for osteoblasts (Wergedal et al. 1990, Mohan \& Baylink 1996). In addition it is the dominant IGF expressed in the growth plate of immature and growing 
rats (Shinar et al. 1993, Wang et al. 1995) and mice (Wang et al. 1995).

Glucocorticoids have many effects that are opposite to the effects of IGF-II. They are growth suppressing in many species including mice (Silbermann et al. 1976), rats (Simmons \& Kunin 1967, Ortoft et al. 1998) and man (Allen et al. 1994) and cause osteoporosis (Orwoll \& Klein 1995). Furthermore they induce involution of the thymus (Franco et al. 1990, Ortoft et al. 1998).

Therefore, we wondered whether IGF-II-transgenic mice are more resistant to the effects of glucocorticoids than their normal controls with respect to growth of the total body, various organs and selected bones.

\section{Materials and Methods}

\section{Animals}

Transgenic (Tg) mice expressing human IGF-II under the control of the $\mathrm{H} 2 \mathrm{~Kb}$ promotor (Tg II mice) were generated as described in detail previously (van Buul-Offers et al. 1995). For these experiments mouse line 74 was used which carries about 100 copies of a mini-gene containing 178 base pairs of exon 5 and exons 7, 8 and 9. As controls, the background strain of the transgenic mice (strain FVB) was used.

The animals were bred and kept under standardized conditions as described previously (van Buul-Offers et al. 1995).

\section{Experimental design}

Experiment 1 Three-week-old female FVB mice were divided into 4 groups of 5 animals. The mice were selected to ensure equal means and standard deviations for length and weight in each group at the start of the experiment. The animals were injected once a day subcutaneously with $0.1 \mathrm{ml}$ vehicle (phosphate-buffered saline (PBS), $\mathrm{pH} 7 \cdot 4$ ) or $0.2 \mu \mathrm{g}, 2 \mu \mathrm{g}$ or $20 \mu \mathrm{g}$ dexamethasone (DXM) per animal per day, 5 days a week for a total time of 4 weeks.

The animals were measured and weighed every week. Snout-tail length was determined under ether anesthesia by the method of Hughes and Tanner (1970). The mice were killed by cervical dislocation under ether anesthesia $2 \mathrm{~h}$ after the last injection. Organs were immediately removed, frozen in liquid nitrogen and weighed to the nearest milligram. The tibiae were carefully dissected out and cleared from adjacent muscle. The length of the tibia was determined on frozen bones using a caliper calibrated to $0.05 \mathrm{~mm}$. The lumbar vertebrae were dissected out and the surrounding soft tissue was removed as much as possible. To further minimize the contribution of muscle tissue to the weight, the vertebrae were immersed in ethanol:ether (1:1) and dried prior to weighing.

Experiment 2 Female FVB and Tg II mice (3 weeks old) were divided into 2 groups of 5 mice each. The animals were injected subcutaneously with $0.1 \mathrm{ml}$ vehicle or $20 \mu \mathrm{g}$ DXM per animal once a day, 5 days a week for a total time of 4 weeks. Body and organ parameters were determined as described in experiment 1 .

\section{Growth plate histomorphometry}

Tibiae were broken near the middle of the diaphysis, decalcified for $24 \mathrm{~h}$ in $0.5 \mathrm{M}$ phosphate-buffered EDTA, $\mathrm{pH} 8.0$, fixed in $3.8 \%$ formalin and embedded in paraffin in a standardized way to ensure proper orientation. Frontal sections $(10 \mu \mathrm{m})$ were cut from ventral to dorsal and proximal to distal. The center of the growth plate was determined as described previously (Smeets \& van Buul-Offers 1983a,b). For each animal, 3 sections situated at the center were stained with a pentachrome stain according to Movat (1955). Histomorphometry was performed using the Image software program on a Macintosh computer. The boundary between the resting zone and the proliferating zone of the growth plate was traced by hand and approximated by a fifth degree polynomial. A similar procedure was carried out on the boundary between the proliferating and the hypertropic zone and between the hypertropic zone and the bone marrow. The Image program then calculates the mean distance between the three polynomes.

\section{Determination of serum IGF-I and IGF-II}

Serum IGF-I and IGF-II concentrations were determined as described before (van Buul-Offers et al. 1994). Briefly, mouse serum was treated with acid and separated over C-18 cartridges (SepPak, Waters Associates, Milford, MA, USA). IGF-I and IGF-II were measured by a heterologous radioimmunoassay using the anti-human IGF-I rabbit antiserum kindly provided by Dr P Gluckman, Auckland, New Zealand (Breier et al. 1991) and an anti-rat-IGF-II monoclonal antibody (Amano Pharmaceuticals Co. Ltd, Osaka, Japan) respectively.

\section{Western ligand blot for IGF binding proteins (IGFBPs)}

Serum IGFBPs were analyzed by polyacrylamide gel electrophoresis and Western ligand blotting according to Hossenlopp et al. (1986) as described previously (van Buul-Offers et al. 1994). Blots were pretreated with 3\% Nonidet P-40 (BDH Laboratory, Poole, Dorset, UK) (30 $\mathrm{min}), 1 \%$ BSA $(60 \mathrm{~min})$ and $0 \cdot 1 \%$ Tween $20(5 \mathrm{~min})$ in TBS buffer $(10 \mathrm{mM}$ Tris- $\mathrm{HCl}, 150 \mathrm{mM} \mathrm{NaCl}, \mathrm{pH}$ $7 \cdot 4)$, incubated with human ${ }^{125} \mathrm{I}$-IGF-II $\left(2 \times 10^{6}\right.$ c.p.m./ blot in $25 \mathrm{ml}$ TBS containing 1\% BSA and 1\% Tween-20 for $4 \mathrm{~h}$ at room temperature) and washed in TBS $(2 \times 15 \mathrm{~min})$. The blotted IGFBPs were visualized by autoradiography on Fuji RX film or on a phospho-imager screen and quantified with the Molecular Imager (BioRad, Hercules, CA, USA). 


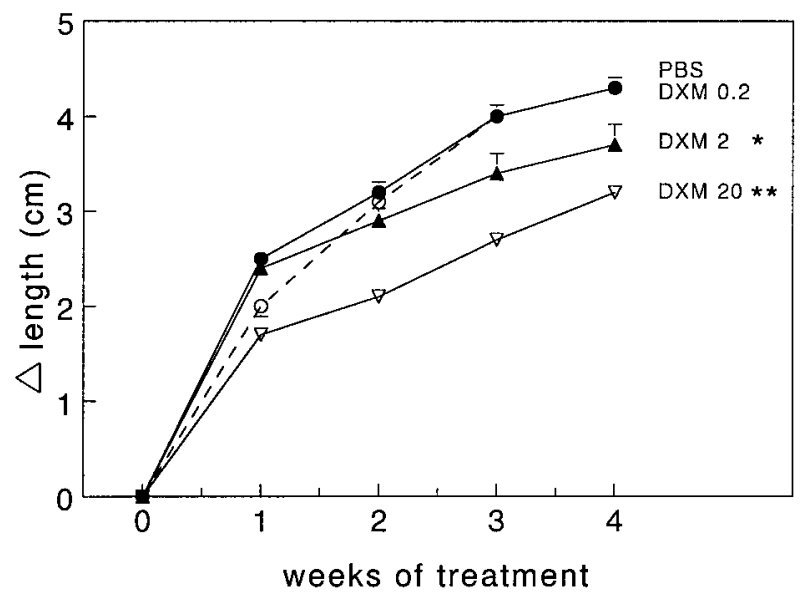

Figure 1 Increase in body length of normal mice during 4 weeks of treatment with PBS $(\bigcirc$, dashed line) or DXM $0.2 \mu \mathrm{g} /$ day $(\mathbf{0})$, $2 \mu \mathrm{g} /$ day $(\boldsymbol{\Delta})$ or $20 \mu \mathrm{g} /$ day $(\nabla)$. Results are means and S.E.M. of 5 animals. ${ }^{*} P<0 \cdot 05 ;{ }^{* *} P<0 \cdot 01$ after 4 weeks of treatment compared with PBS controls (Scheffé's test).

\section{Statistical analysis}

The differences between groups were analyzed by Scheffe's test if multiple doses were compared. For comparison of two groups, a two-tailed Student's $t$-test was used.

\section{Results}

Dose-effect relationship of dexamethasone in normal (FVB) mice

Effects on body length, body weight, tibia, humerus and lumbar vertebrae Different doses of DXM were tested in normal mice in order to find a dose that inhibited growth without causing starvation or death.

The increment in length during the 4 weeks of the experiment is shown in Fig. 1. DXM inhibited growth dose dependently. The growth reduction was signifcant at a dose of 2 and $20 \mu \mathrm{g} /$ day.

Body weight decreased in parallel to body length. Consequently, weight-for-length remained constant except at the highest dose of DXM when it decreased by 10\% (Table 1).

In contrast to body length, tibia length was only slightly affected by DXM. Therefore the width of the growth plate was determined histomorphometrically in the PBS and the DXM $20 \mu \mathrm{g} /$ day groups at the end of the experiment. The total width of the growth plate slightly diminished in the DXM-treated animals mainly due to a decrease in the width of the proliferative layer. The hypertropic zone remained unaffected (Table 1).

The weight of the tibia, humerus and lumbar vertebrae decreased dose-dependently following administration of
DXM but the decrease was only statistically significant for the lumbar vertebrae (Table 1).

Effects on various organs For all organs studied, a dose-dependent decrease in weight was obtained. However, the various organs have a different sensitivity towards the growth inhibitory effect of DXM.

Kidney weight decreased in proportion to body weight, while liver and muscle weight were proportionally more affected (Table 1). Moreover, the highest dose of DXM dramatically decreased the weight of the thymus to about $30 \%$ of vehicle-treated animals. Spleen weight was already decreased by $2 \mu \mathrm{g} /$ day and was reduced to about $40 \%$ at the highest DXM dose.

\section{Body and organ size in normal and transgenic animals}

Table 2 summarizes the body and organ parameters of normal and IGF-II-transgenic animals. Overexpression of IGF-II did not modify body length or body weight as reported previously (van Buul-Offers et al. 1995). Consequently, weight-for-length was identical in the vehicletreated FVB and transgenic mice $(1.21 \pm 0.03 \mathrm{~g} / \mathrm{cm}$ vs $1 \cdot 21 \pm 0.03 \mathrm{~g} / \mathrm{cm})$. There was a tendency towards lower weights for tibia, humerus and lumbar vertebrae in the transgenic mice but the difference did not reach statistical significance. Transgenic animals also showed a significant increase in the weight of the spleen and thymus as described previously (van Buul-Offers et al. 1995).

\section{Effect of dexamethasone in normal and IGF-II-transgenic mice}

Based on the results of experiment 1, a dose of $20 \mu \mathrm{g}$ DXM was chosen to compare its effects in normal and Tg mice.

Effect on body length and weight The increment in body length of both types of mice during the treatment period is shown in Fig. 2. Dexamethasone $20 \mu \mathrm{g} /$ day decreased the growth velocity from $4 \cdot 2 \mathrm{~cm} / 4$ weeks to $3 \cdot 3$ $\mathrm{cm} / 4$ weeks $(78 \%)$ in the normal mice. In the transgenic animals it decreased from $4.3 \mathrm{~cm} / 4$ weeks to $3 \cdot 4 \mathrm{~cm} / 4$ weeks (81\%). Although the body length of $\mathrm{Tg}$ II mice tended to be less affected by DXM, the difference did not reach statistical significance.

In contrast, transgenic animals lost more weight when treated with DXM than FVB mice. Their weight-forlength was $1.04 \pm 0.02 \mathrm{~g} / \mathrm{cm}$ vs $1.12 \pm 0.02 \mathrm{~g} / \mathrm{cm}$ in the FVB mice $(P<0 \cdot 05$, Student's $t$-test $)$ at the end of treatment.

Effect on individual bones The effect of DXM on tibia, humerus and lumbar vertebrae is shown in Fig. 3. The length of the tibia decreased in the FVB but not in the Tg II mice. Likewise, tibia weight decreased following DXM in the FVB mice but not in the Tg II mice $(13 \cdot 4 \% \pm 1 \cdot 1 \%$ 
Table 1 Dose-effect relationship of DXM on body and organ growth in normal FVB mice. All organ weights in the PBS group are expressed in mg. All parameters in the DXM-treated mice are expressed as a percentage of the PBS group

\begin{tabular}{|c|c|c|c|c|c|c|c|c|}
\hline & \multicolumn{2}{|l|}{ PBS } & \multicolumn{2}{|c|}{ DXM $0 \cdot 2 \mu \mathrm{g} /$ day } & \multicolumn{2}{|c|}{ DXM $2 \mu \mathrm{g} /$ day } & \multicolumn{2}{|c|}{ DXM $20 \mu \mathrm{g} /$ day } \\
\hline$\Delta$ Length/4 weeks $(\mathrm{cm})$ & $4 \cdot 3$ & $0 \cdot 1$ & $100 \cdot 0$ & $2 \cdot 5$ & $86 \cdot 0$ & $5 \cdot 0^{*}$ & $74 \cdot 0$ & $2 \cdot 1^{*}$ \\
\hline Weight/length $(\mathrm{mg} / \mathrm{mm})$ & $110 \cdot 7$ & $2 \cdot 4$ & $99 \cdot 7$ & $2 \cdot 6$ & $98 \cdot 6$ & $2 \cdot 5$ & $89 \cdot 6$ & $1.9 *$ \\
\hline Tibia length (mm) & $16 \cdot 8$ & $0 \cdot 3$ & $102 \cdot 1$ & $2 \cdot 0$ & $99 \cdot 0$ & $0 \cdot 8$ & $98 \cdot 9$ & $1 \cdot 3$ \\
\hline Total growth plate $(\mu \mathrm{m})$ & $148 \cdot 3$ & $1 \cdot 3$ & nd & nd & nd & nd & $94 \cdot 3$ & $2 \cdot 6$ \\
\hline Tibia & $49 \cdot 9$ & $2 \cdot 9$ & $98 \cdot 8$ & $4 \cdot 3$ & $88 \cdot 8$ & $2 \cdot 6$ & $89 \cdot 8$ & $3 \cdot 6$ \\
\hline Humerus & $32 \cdot 7$ & $1 \cdot 4$ & $97 \cdot 8$ & $2 \cdot 8$ & $89 \cdot 7$ & $4 \cdot 0$ & $90 \cdot 1$ & $1 \cdot 7$ \\
\hline Lumbar vertebrae & $61 \cdot 1$ & $2 \cdot 9$ & $96 \cdot 5$ & $3 \cdot 5$ & $87 \cdot 7$ & $4 \cdot 0$ & $81 \cdot 7$ & $3 \cdot 5^{*}$ \\
\hline Kidney & $257 \cdot 5$ & $9 \cdot 5$ & $100 \cdot 0$ & $3 \cdot 2$ & $94 \cdot 1$ & $4 \cdot 4$ & $88 \cdot 2$ & $3 \cdot 3$ \\
\hline Liver & $980 \cdot 0$ & $30 \cdot 0$ & $96 \cdot 0$ & $2 \cdot 1$ & $84 \cdot 0$ & $3 \cdot 5^{*}$ & $80 \cdot 9$ & $3 \cdot 5^{*}$ \\
\hline
\end{tabular}

${ }^{*} P<0.05$ compared with PBS group in Scheffé's test. $\uparrow P<0.05$ compared with PBS group in Student's $t$-test, nd= not determined.

vs $1 \cdot 5 \% \pm 3 \cdot 4 \%, P<0 \cdot 05)$. Consequently, tibia weight-forlength was decreased by DXM in the FVB mice (from $2 \cdot 87 \pm 0.1$ to $2.61 \pm 0.03 \mathrm{mg} / \mathrm{mm}$ ) but not in the transgenic animals (from $2.73 \pm 0.03$ to $2.75 \pm 0.1 \mathrm{mg} / \mathrm{mm}$ ).

The results for the humerus were similar to the results for the tibia. The weight of the humerus decreased much more following DXM in the FVB animals than in the transgenic mice. Humerus weight-for-length significantly decreased in the normal mice from $2.76 \pm 0.05 \mathrm{mg} / \mathrm{mm}$ to $2 \cdot 36 \pm 0 \cdot 04$ ( $P \leq 0 \cdot 01$ Student's $t$-test). In the transgenic animals humerus weight-for-length decreased slightly from $2.56 \pm 0.05$ to $2 \cdot 42 \pm 0.02$ (not significant, Student's $t$-test).
In contrast, this sparing effect was not seen in the lumbar vertebrae. DXM decreased lumbar vertebrae weight equally in both strains of mice.

Effect on organ weight The weights of the kidney, liver, spleen and M. quadriceps femoris decreased following DXM administration in a similar manner in both mice strains (Fig. 4).

Thymus weight was higher in the non-treated transgenic animals than in the FVB mice. Dexamethasone decreased the weight of the thymus more in the transgenic than in the control animals (43\% vs $29 \% ; P<0 \cdot 05$, Student's $t$-test).

Table 2 Body and organ growth of normal (FVB) and IGF-II-transgenic mice (Tg II) $(n=5)$. All organ weights are expressed in $\mathrm{mg}$

\begin{tabular}{|c|c|c|c|c|}
\hline & \multicolumn{2}{|l|}{ FVB } & \multicolumn{2}{|l|}{ Tg II } \\
\hline & Mean & S.E.M. & Mean & S.E.M. \\
\hline Body length (cm) & $18 \cdot 1$ & $0 \cdot 3$ & $17 \cdot 9$ & $0 \cdot 1$ \\
\hline Body weight (g) & $22 \cdot 0$ & $0 \cdot 7$ & $21 \cdot 6$ & $0 \cdot 05$ \\
\hline Weight/length $(\mathrm{g} / \mathrm{cm})$ & $1 \cdot 21$ & $0 \cdot 03$ & $1 \cdot 21$ & 0.03 \\
\hline Tibia length (mm) & $17 \cdot 11$ & $0 \cdot 23$ & $16 \cdot 58$ & $0 \cdot 13$ \\
\hline Humerus length (mm) & $11 \cdot 52$ & $0 \cdot 1$ & $11 \cdot 58$ & $0 \cdot 1$ \\
\hline Tibia weight & $49 \cdot 1$ & $1 \cdot 8$ & $45 \cdot 3$ & $0 \cdot 8$ \\
\hline Humerus & $31 \cdot 8$ & $0 \cdot 8$ & $29 \cdot 7$ & $0 \cdot 8$ \\
\hline Lumbar vertebrae & $66 \cdot 6$ & $2 \cdot 5$ & $63 \cdot 8$ & $1 \cdot 7$ \\
\hline Kidney & $263 \cdot 0$ & $15 \cdot 2$ & $262 \cdot 4$ & $6 \cdot 2$ \\
\hline Liver & $1026 \cdot 9$ & $53 \cdot 5$ & $1023 \cdot 4$ & $29 \cdot 7$ \\
\hline M. quadriceps femoris & $242 \cdot 1$ & $12 \cdot 3$ & $241 \cdot 1$ & $4 \cdot 9$ \\
\hline Thymus & $63 \cdot 6$ & $3 \cdot 4$ & $104 \cdot 4$ & $1 \cdot 4^{*}$ \\
\hline Spleen & $90 \cdot 2$ & $4 \cdot 5$ & $117 \cdot 1$ & $2 \cdot 1^{\text {* }}$ \\
\hline
\end{tabular}

${ }^{*} P<0.05$ compared with FVB mice (Student's $t$-test).

IGF-II values in FVB mice are from measurements of pooled sera $(n=5)$. 


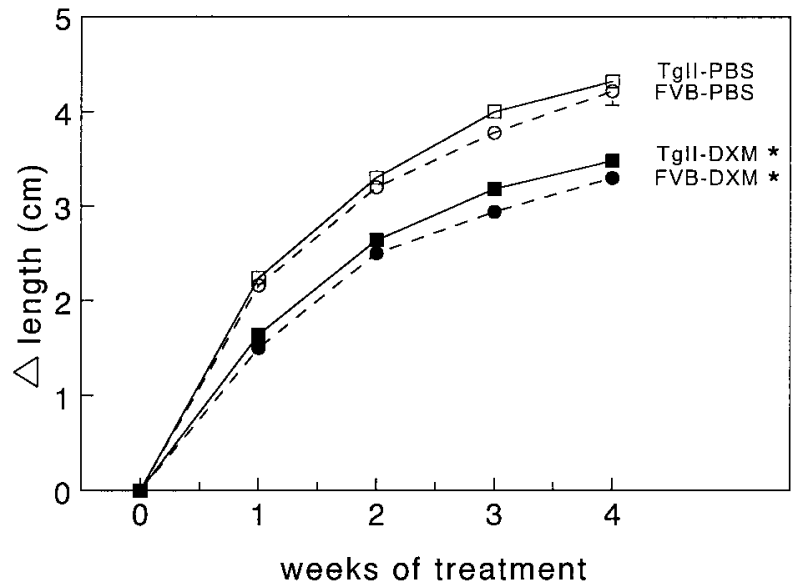

Figure 2 Increase in body length during 4 weeks of treatment with PBS in normal $(\mathrm{FVB})(\mathrm{O}$, dashed line) or transgenic (Tg II) $(\square$, solid line) mice or with DXM $(20 \mu \mathrm{g} /$ day) in normal ( dashed line) and transgenic ( $\mathbf{\square}$, solid line) mice. Results are means and S.E.M. of 5 animals. ${ }^{*} P<0.05$ after 4 weeks of treatment compared with PBS controls (Student's t-test).

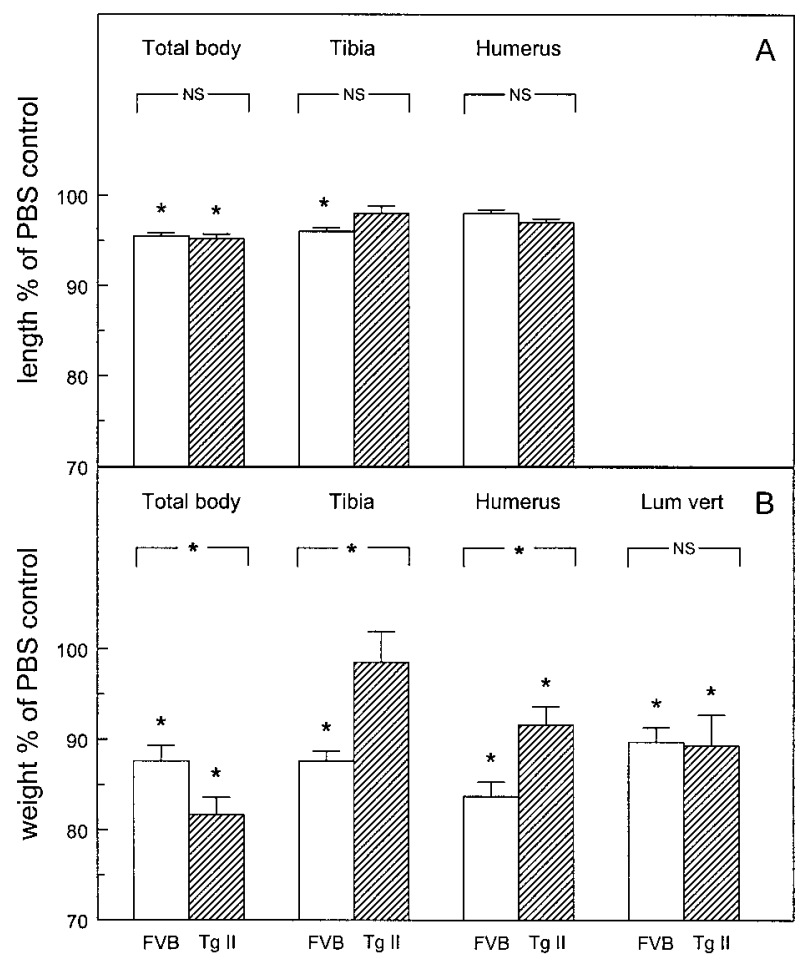

Figure 3 Effect of DXM (20 $\mu$ g/day) in normal (FVB) (open bars) and transgenic ( $\mathrm{Tg}$ II) (hatched bars) mice on the length (A) and weight (B) of tibia, humerus and lumbar vertebrae (Lum vert). Results are means and S.E.M. of 5 animals, expressed as a percentage of their respective PBS controls. An asterisk on top of the bar indicates $P<0.05$ when compared with the PBS controls (Student's t-test). NS, not significant.

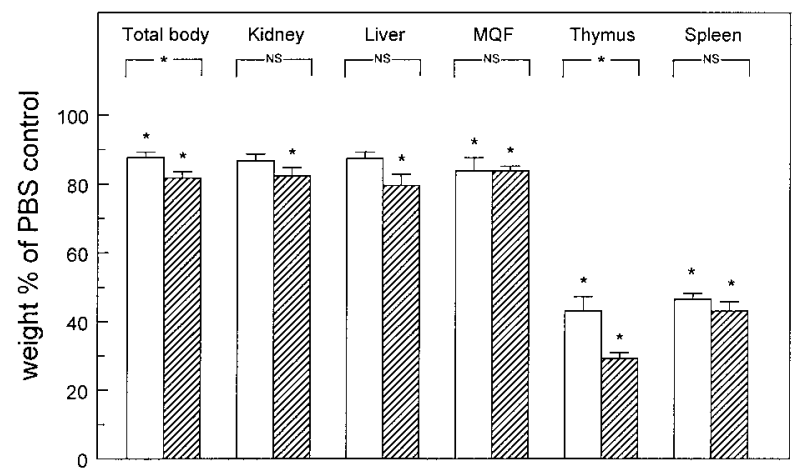

Figure 4 Effect of DXM (20 $\mu$ g/day) in normal (open bars) and transgenic (hatched bars) mice on selected organ weights. Results are means and S.E.M. of 5 animals. An asterisk on top of the bar indicates $P<0.05$ when compared with the PBS controls (Student's t-test). MQF, M. quadriceps femoris. NS, not significant.

IGF-I, IGF-II and IGFBPs in serum Serum IGF-I and IGF-II concentrations in the different treatment groups are shown in Table 3. The levels of IGF-I were somewhat higher in the transgenic mice. Dexamethasone increased the levels of IGF-I in normal mice but not in transgenic mice. The IGF-II levels in the Tg II mice were more than 40-fold higher than in normal mice. Dexamethasone significantly decreased the IGF-II levels but they still remained more than 20 -fold higher than in the normal mice.

The IGFBPs were analyzed by Western ligand blotting using radiolabeled IGF-II (Fig. 5). The sera of both mice strains showed the expected bands at $41.5 \mathrm{kDa}$ (most probably the IGFBP-3 doublet), $30 \mathrm{kDa}, 28.5 \mathrm{kDa}$, $26.5 \mathrm{kDa}$ and $24 \mathrm{kDa}$ (probably IGFBP-4). In normal mice, DXM only affected the $24 \mathrm{kDa}$ band which was significantly decreased. In transgenic mice, all IGFBPs were increased (significantly higher levels for the bands situated at $41.5 \mathrm{kDa}, 30 \mathrm{kDa}$, and $26.5 \mathrm{kDa}$ ). In these animals, DXM reduced the $24 \mathrm{kDa}, 26.5 \mathrm{kDa}$ and $38 \cdot 5 \mathrm{kDa}$ bands.

\section{Discussion}

Glucocorticoids exert a profound catabolic effect on experimental animals and in man. To date, growth

Table 3 Serum levels of IGF-I and IGF-II (ng/ml) in normal (FVB) and transgenic mice treated with PBS or DXM $20 \mu \mathrm{g} /$ day. Results are means \pm S.E.M. of 5 animals

\begin{tabular}{|c|c|c|c|c|}
\hline & \multicolumn{2}{|l|}{ FVB mice } & \multicolumn{2}{|c|}{ Transgenic mice } \\
\hline & PBS & DXM & PBS & DXM \\
\hline IGF-I & $406 \pm 23$ & $472 \pm 8^{*}$ & $468 \pm 15$ & $434 \pm 22$ \\
\hline IGF-II & $2 \cdot 8$ & $3 \cdot 3$ & $114 \pm 26$ & $72 \pm 14^{*}$ \\
\hline
\end{tabular}




\section{A}
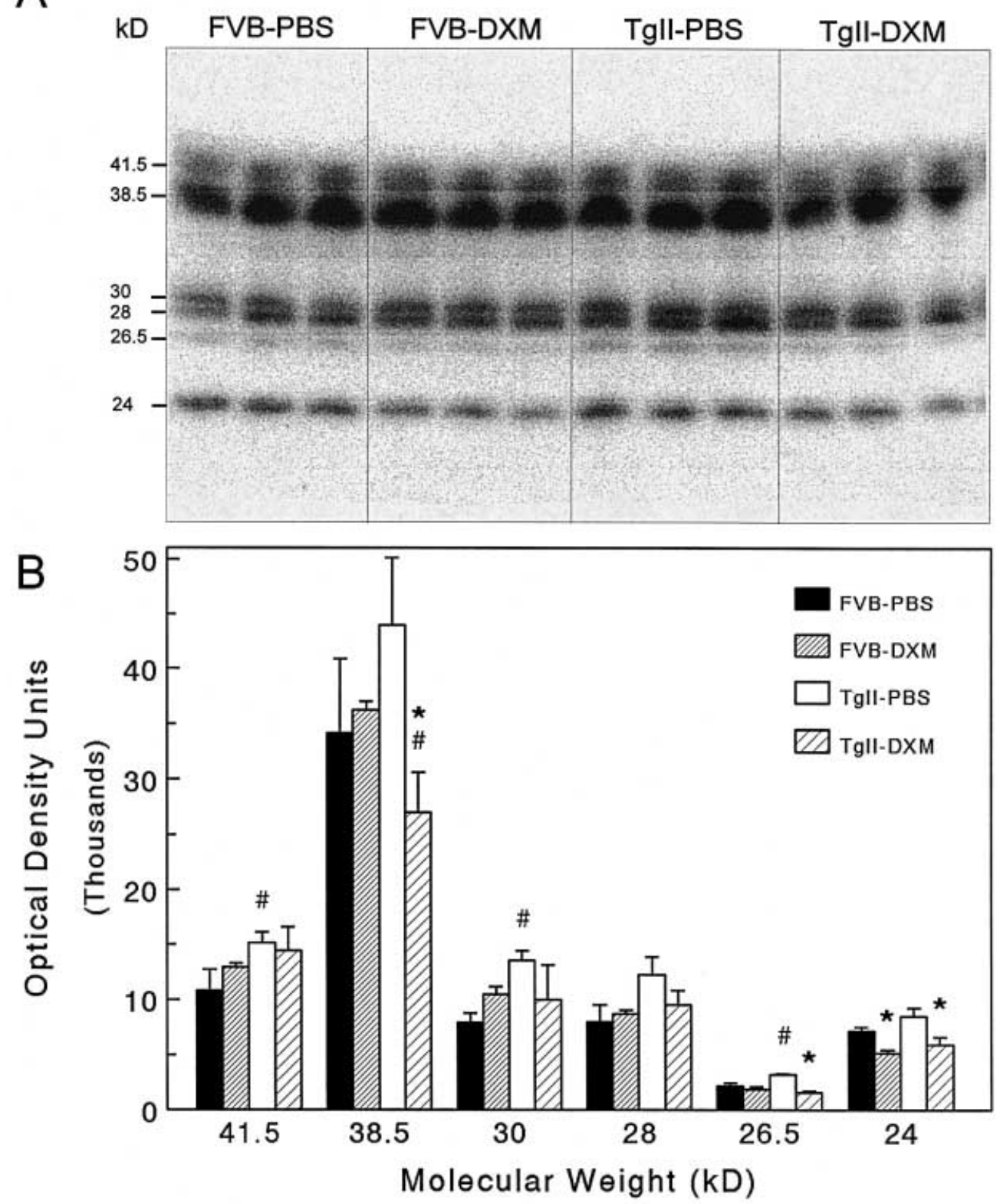

Figure 5 (A) Western ligand blot of $3 \mu$ l serum from normal (FVB) or transgenic (Tg II) mice treated with PBS or DXM $(20 \mu \mathrm{g} /$ day $)$. In each group the sera from the 3 animals with a weight closest to the mean were analyzed. (B) Quantification of the ligand blot shown in the upper panel by directly exposing the blot to the phospho-imager screen. The bands were analyzed with the Molecular Imager program. ${ }^{\star} P<0 \cdot 05$ PBS versus DXM; \#P<0.05 FVB versus Tg II (Student's $t$-test).

hormone (GH) and IGF-I were used to counteract these undesirable effects but the results of these studies have been a partial response at best (Laron et al. 1963, Altman et al. 1992, Rivkees et al. 1994, Ortoft et al. 1998). IGF-II has some biological effects that may counteract the catabolic effects of glucocorticoids but, to the best of our knowledge, has never been tried in this situation before.
First, we determined a dose for DXM that would inhibit growth but would still allow the animals to gain weight. Therefore, in the first experiment we administered three different doses of DXM to normal mice. Longitudinal growth was already inhibited at $2 \mu \mathrm{g} /$ day and was one of the most sensitive parameters. At the growth plate level we found a slight decrease in total growth plate 
width in DXM-treated animals. This was due to a significant reduction in the proliferative zone in the steroid-treated mice. This is in line with data from Silbermann and Kadar (1977) who reported a small decrease in total width which was totally accounted for by the significant decrease in the width of the proliferative layer. In a similar experimental design, Altman et al. (1992) found a significant decrease in total growth plate width. Their strain of mice was, however, different from ours since they reported a total growth plate width that is 2.5 times as large as our measurements.

The various body parts of normal mice have a different susceptibility to the inhibiting effects of DXM. Tibia, humerus and lumbar vertebrae weight decreased less than total body weight. Liver, kidney and skeletal muscle paralleled total body weight. The lymphoid organs, thymus and spleen, were most vulnerable to glucocorticoid administration. The deleterious effect of glucocorticoids on the thymus was also reported in rats and is probably caused by an increased rate of apoptosis of the thymocytes (Zucker et al. 1994).

Since IGF-II and glucocorticoids have several antagonistic actions on body growth, lymphoid organs and bone, the effect of DXM was studied in animals that have high circulating levels of IGF-II. Increased levels of IGF-II were obtained by creating transgenic mice in which the human IGF-II gene was placed under the control of the $\mathrm{H} 2 \mathrm{~Kb}$ promoter. In this model, the expression of the transgene is ubiquitous with very high expression in spleen and thymus (van Buul-Offers et al. 1995, Van Der Ven et al. 1997). In addition to the high expression of IGF-II in various organs, the serum levels for IGF-II were increased 40-fold. Therefore, in this model, the overstimulation by IGF-II occurs at the endocrine and the paracrine/ autocrine level.

Western ligand blot analysis of the serum of transgenic animals showed an increase of the binding proteins of the $41.5 \mathrm{kDa}$ band (most probably an IGFBP-3 species), $30 \mathrm{kDa}$ and $26.5 \mathrm{kDa}$ (probably a glycosylated form of IGFBP-4). In other IGF-II-transgenic mouse models increased levels of IGFBP-2 (Rogler et al. 1994, Wolf et al. 1994), IGFBP-1 and IGFBP-5 have been noted (Rogler et al. 1994).

A drop in the serum level of IGF-I has often been observed after IGF-II administration or IGF-II overproduction (Douglas et al. 1991, Koea et al. 1992, Rogler et al. 1994, Conlon et al. 1995, Wolf et al. 1995). The reduction in serum IGF-I is most likely due to displacement of IGF-I from the binding proteins in the presence of high concentrations of IGF-II (Blackburn et al. 1997). In these models the concomitant decrease in IGF-I may have masked some biological effects of IGF-II. In our transgenic mice, IGF-I levels were unchanged. We speculate that the induction of several binding proteins has increased the binding capacity of the transgenic mouse serum and therefore prevented displacement of IGF-I.
IGF-II-transgenic and normal mice were simultaneously treated with $20 \mu \mathrm{g}$ DXM per animal per day. This dose of DXM was chosen since it caused a significant growth retardation without starvation. In several reports on the effect of glucocorticoids in rodents, doses were used that induced a significant loss of weight (Simmons \& Kunin 1967, Yang et al. 1994, Lo et al. 1996). In this study, the mice kept gaining weight and the weight-forlength ratio decreased by only $10 \%$.

IGF-II overexpression did not affect longitudinal growth in this model as described previously (van Buul-Offers et al. 1995) nor did it change the length of the tibia and the humerus. The role of IGF-II in postnatal longitudinal growth, therefore, appears to be limited. The physiological meaning of the high levels of IGF-II in the growth plate when studied by in situ hybridization analysis (Shinar et al. 1993, Wang et al. 1995) remains unclear.

The inhibition of longitudinal growth caused by DXM was not prevented by overexpression of IGF-II.

Transgenic animals lost slightly more weight under DXM treatment than FVB mice. This increased weight loss is not reflected in any of the organs studied. During the dissection of the animals we noticed little subcutaneous fat in the DXM-treated transgenic animals. We speculate, therefore, that the Tg II mice have an increased susceptibility to the lipolytic effect of DXM. Reduced fat mass has been reported in other IGF-II-transgenic mice (Rogler et al. 1994, Ward et al. 1994).

IGF-II mRNA and protein are highly expressed in lymphoid tissues such as the thymus and the spleen and cause overgrowth of the thymus in IGF-II-transgenic mice (van Buul-Offers et al. 1995, Van Der Ven et al. 1997). The increase in size of the thymus in the transgenic animals is predominantly due to an increase in cortical thickness with elevated numbers of $\mathrm{T}$ lymphocytes (Kooijman et al. 1995). Despite the high concentrations of IGF-II in these lymphoid organs, no protective effect of IGF-II was found against the DXM-induced involution of the thymus and spleen. We have excluded the possibility that DXM had switched-off the transgene expression in thymus and spleen since there was no difference in signal intensity for IGF-II measured by in situ hybridization or immunohistochemistry between controls and DXMtreated transgenic mice (data not shown).

Dexamethasone caused equal growth inhibition of liver, kidneys and muscle in control and transgenic mice. A different picture was seen in the skeleton. The weight of the tibia and the humerus was better maintained in the DXM-treated transgenic animals. There are several hypotheses to explain this observation. The first explanation may lie in the choice of the $\mathrm{H} 2 \mathrm{~Kb}$ promoter to drive the transgene. The $\mathrm{H} 2 \mathrm{~Kb}$ gene is highly expressed in bone marrow cells that lie in close proximity to the bone trabeculae (Koster JG personal communication). Transgenically made IGF-II may, therefore, be locally present in large amounts and stimulate bone formation. Indeed, 
IGF-II is identical to skeletal growth factor (Mohan et al. 1988) and is present in large quantities in bone (Frolik et al. 1988). IGF-II/skeletal growth factor is produced by and is mitogenic for osteoblasts (Wergedal et al. 1990, Mohan \& Baylink 1996). There are, of course, many alternative explanations e.g. glucocorticoids may enhance the effect of IGF-II in a tissue-specific manner e.g. by inducing components of the IGF-II signal transducing system in osteoblasts. Since we did not separate the bone marrow from the bones, the increased weight of tibia and humerus may be due to an increase in the weight of the bone marrow. It is unclear why IGF-II did not preserve the lumbar vertebrae weight in the DXM-treated transgenic animals.

IGF-I serum concentrations were not decreased in DXM-treated mice, which is in line with data reported in normal rats (Luo \& Murphy 1989, Ortoft et al. 1998).

The serum levels of IGF-II in the DXM-treated transgenic animals decreased by 35\%. Different explanations can be offered. First, direct effects of glucocorticoids on IGF-II gene expression have been reported (Li et al. 1998). In our animals IGF-II transgene expression was not altered in the thymus, spleen and bone marrow (data not shown). Secondly, IGF-II is highly expressed in the thymus, the spleen and the bone marrow of these transgenic mice. Dexamethasone did not affect the level of IGF-II mRNA expression per cell but it dramatically decreased the number of cells in these organs. Lastly, DXM decreased the levels of some binding protein proteins which may function as an important reservoir for IGF-II in the serum.

Indeed, in Tg II mice DXM lowered the intensity of the binding protein bands on Western ligand blots at $38.5 \mathrm{kDa}$ (IGFBP-3), $26.5 \mathrm{kDa}$ and $24 \mathrm{kDa}$ (probably IGFBP-4). In the normal mice we only noticed an effect on the $24 \mathrm{kDa}$ species. In the literature, there are no data available for the effect of glucocorticoids on IGFBPs in mice. In rats, however, DXM was reported to increase the synthesis of IGFBP-1 and IGFBP-3 (Luo \& Murphy 1990, Rodgers et al. 1995) and decrease the levels of IGFBP-2 and IGFBP-4 (Rodgers et al. 1995). Our results do not support a significant effect of DXM on IGFBP-3 but do confirm the reduction of IGFBP-4 (24 kDa band) in mice.

Our results do not explain the mechanism of growth inhibition by glucocorticoids but refute some hypotheses offered by others, at least in mice. Since GH and IGF-I have important effects on longitudinal growth, many investigators have looked for an interference by glucocorticoids with the GH-IGF-growth plate system. Interactions of glucocorticoids with almost every step of this pathway have been published such as the inhibition of growth hormone secretion (Giustina \& Wehrenberg 1992), down-regulation of the growth hormone receptor (King \& Carter-Su 1995), the induction of circulating inhibitors of IGF action (Unterman \& Phillips 1985), modulation of IGFBPs (Miell et al. 1994), the inhibition of IGF-I synthesis (Luo \& Murphy 1989), down-regulation of the type I IGF receptors (Robinson et al. 1993) or interference with post receptor events (Klaus et al. 1996).

Since serum IGF-I levels did not decrease after 4 weeks of DXM administration, interference with GH secretion or IGF-I synthesis is unlikely. Our data also fail to support the hypothesis that glucocorticoids significantly increase the IGFBPs and therefore decrease the bioavailability of the IGFs. We cannot rule out or prove an effect of glucocorticoids on IGF bioactivity or on the induction of inhibitors of IGF action.

In conclusion, this study indicates that overproduction of IGF-II by a transgenic approach does not prevent glucocorticoid-induced inhibition of growth. Of all the body parts tested only tibia and humerus were partly protected against the catabolic effect of glucocorticoids. Further experiments are needed to determine how IGF-II and glucocorticoids interact in bone metabolism.

\section{Acknowledgements}

We would like to thank Ingrid van de Brink and Annette de Zeeuw for the tender loving mouse care. This study was supported by a grant from the Belgian Study Group for Pediatric Endocrinology to R R.

\section{References}

Allen DB, Mullen ML \& Mullen B 1994 A meta-analysis of the effect of oral and inhaled corticosteroids on growth. Journal of Allergy and Clinical Immunology 93 967-976.

Altman A, Hochberg Z \& Silbermann M 1992 Interactions between growth hormone and dexamethasone in skeletal growth and bone structure of the young mouse. Calcified Tissue International $\mathbf{5 1}$ 298-304.

Blackburn A, Dressendorfer RA, Blum WF, Ehard M, Brem G, Strasburger CJ \& Wolf E 1997 Interactions of insulin-like growth factor-II (IGF-II) and growth hormone in vivo: circulating levels of IGF-I and IGF-binding proteins in transgenic mice. European Journal of Endocrinology 137 701-708.

Breier BH, Gallaher BW \& Gluckman PD 1991 Radioimmunoassay for insulin-like growth factor-I: solutions to some potential problems and pitfalls. Journal of Endocrinology 128 347-357.

van Buul-Offers SC 1996 Insulin-like growth factor-II in the cycle of life. Biomedical Reviews 5 65-71.

van Buul-Offers SC, Hoogerbrugge CM, Branger J, Feijlbrief M \& Van den Brande JL 1988 Growth-stimulating effects of somatomedin-/insulin-like peptides in Snell dwarf mice. Hormone Research 29 229-236.

van Buul-Offers SC, Reijnen-Gresnigt MG, Hoogerbrugge CM, Bloemen RJ, Kuper CF \& Van den Brande JL 1994 Recombinant insulin-like growth factor-II inhibits the growth-stimulating effect of growth hormone on the liver of Snell dwarf mice. Endocrinology 135 977-985.

van Buul-Offers SC, De Haan K, Reijnen-Gresnigt MG, Meinsma D, Jansen M, Oei SL, Bonte EJ, Sussenbach JS \& Van den Brande JL 1995 Overexpression of human IGF-II in transgenic mice causes increased growth of the thymus. Journal of Endocrinology 144 491-502.

Conlon MA, Francis GL, Tomas FM, Wallace JC, Howarth GS \& Ballard FJ 1995 Continuous 14-day infusion of IGF-II increases the 
growth of normal female rats, but exhibits a lower potency than IGF-I. Journal of Endocrinology 144 91-98.

Douglas RG, Gluckman PD, Ball K, Breier B \& Shaw JHF 1991 The effects of infusion of insulin-like growth factor (IGF)-I, IGF-II, and insulin on glucose and protein metabolism in fasted lambs. Journal of Clinical Investigation 88 614-622.

Franco P, Marelli O, Lattuada D, Locatelli V, Cocchi D \& Muller EE 1990 Influence of growth hormone on the immunosuppressive effect of prednisolone in mice. Acta Endocrinologica 123 339-344.

Frolik CA, Ellis LF \& Williams DC 1988 Isolation and characterization of insulin-like growth factor-II from human bone. Biochemical and Biophysical Research Communications 151 1011-1018.

Geenen V, Achour I, Robert F, Vandersmissen E, Sodoyez JC, Defresne MP, Boniver J, Lefebvre PJ \& Franchimont P 1993 Evidence that insulin-like growth factor 2 (IGF2) is the dominant thymic peptide of the insulin superfamily. Thymus 21 115-127.

Giustina A \& Wehrenberg WB 1992 The role of glucocorticoids in the regulation of growth hormone secretion. Trends in Endocrinology and Metabolism 3 306-311.

Glasscock GF, Hein AN, Miller JA, Hintz RL \& Rosenfeld RG 1992 Effects of continuous infusion of insulin-like growth factor I and II, alone and in combination with thyroxine or growth hormone, on the neonatal hypophysectomized rat. Endocrinology 130 203-210.

Gluckman PD \& Ambler GR 1993 What is the function of circulating insulin-like growth factor-2 in postnatal life? Molecular and Cellular Endocrinology 92 C1-C3.

Hossenlopp P, Seurin D, Segovia-Quinson B, Hardouin S \& Binoux M 1986 Analysis of serum insulin-like growth factor binding proteins using western blotting: use of the method for titration of the binding proteins and competitive binding studies. Analytical Biochemistry 154 138-143.

Hughes PCR \& Tanner JM 1970 A longitudinal study of the growth of the blackhooded rat: methods of measurement and rates of growth for skull, limbs, pelvis, nose-rump and tail lengths. Journal of Anatomy 106 349-370.

King APJ \& Carter-Su C 1995 Dexamethasone-induced antagonism of growth hormone $(\mathrm{GH})$ action by down-regulation of $\mathrm{GH}$ binding in 3T3-F442A fibroblasts. Endocrinology 136 4796-4803.

Klaus G, Jux C, Leiber K, Hugel U \& Mehls O 1996 Interaction between insulin-like growth factor I, growth hormone, 1 alfa, 25dihydroxyvitamin D3 and steroids on epiphyseal chondrocytes. Acta Paediatrica Scandinavica (Suppl) 417 69-71.

Koea JB, Breier BH, Shaw JHF \& Gluckman PD 1992 A possible role for IGF-II: evidence in sheep for in vivo regulation of IGF-Imediated protein anabolism. Endocrinology $1302423-2425$.

Kooijman R, van Buul-Offers SC, Scholtens LE, Schuurman H-J, Van den Brande LJ \& Zegers BMJ 1995 T cell development in insulin-like growth factor-II-transgenic mice. Journal of Immunology $1545736-5745$.

Laron Z, Arie BZ \& Kende S 1963 Effectiveness of growth hormone to prevent the alterations produced by 6-methylprednisolone (Medrol) on the growing bone in rats. Endocrinology 72 470-473.

Li J, Saunders JC, Fowden AL, Dauncey MJ \& Gilmour RS 1998 Transcriptional regulation of insulin-like growth factor-II gene expression by cortisol in fetal sheep during late gestation. Journal of Biological Chemistry 273 10586-10593.

Lo HC, Hinton PS, Yang H, Unterman TG \& Ney DM 1996 Insulin-like growth factor I, but not growth hormone attenuates dexamethasone-induced catabolism in parenterally fed rats. Journal of Parenteral and Enteral Nutrition 20 171-177.

Luo J \& Murphy LJ 1989 Dexamethasone inhibits growth hormone induction of insulin-like growth factor-I (IGF-I) messenger ribonucleic acid (mRNA) in hypophysectomized rats and reduces IGF-I mRNA abundance in the intact rat. Endocrinology 125 165-171.

Luo J \& Murphy LJ 1990 Regulation of insulin-like growth factor binding protein-3 expression by dexamethasone. Molecular and Cellular Endocrinology 74 213-219.
Miell JP, Buchanan CR, Norman MR, Maheshwari HG \& Blum WF 1994 The evolution of changes in immunoreactible serum insulin-like growth factors (IGFs), IGF binding proteins, circulating growth hormone $(\mathrm{GH})$ and $\mathrm{GH}$ binding protein as a result of short term dexamethasone treatment. Journal of Endocrinology 142 547-554.

Mohan S \& Baylink DJ 1996 Insulin-like growth factor system components and the coupling of bone formation to resorption. Hormone Research 45 59-62.

Mohan S, Jennings JC, Linkhart TA \& Baylink DJ 1988 Primary structure of human skeletal growth factor: homology with human insulin-like growth factor-II. Biochimica et Biophysica Acta 966 44-55.

Movat HZ 1955 Demonstration of all connective tissue elements in a single section: pentachrome stains. Archives of Pathology 60 289-295.

Ortoft G, Gronbaek H \& Oxlund H 1998 Growth hormone administration can improve growth in glucocorticoid-injected rats without affecting the lymphocytopenic effect of the glucocorticoid. Growth Hormone and IGF Research 8 251-264.

Orwoll ES \& Klein RF 1995 Osteoporosis in men. Endocrine Reviews 16 87-116.

Ren-Qiu Q, Ruelicke T, Hassam S, Haselbacher GK \& Schoenle EJ 1993 Systemic effects of insulin-like growth factor-II produced and released from Wilms tumour tissue. European Journal of Pediatrics 152 102-106.

Rivkees SA, Danon M \& Herrin J 1994 Prednisone dose limitation of growth hormone treatment of steroid-induced growth failure. Journal of Pediatrics 125 322-325.

Robinson GM, Spencer GSG, Berry CJ, Dobbie PM, Hodgkinson SC \& Bass JJ 1993 Evidence of a role for growth hormone, but not for insulin-like growth factors-I or -II in the growth of the neonatal rat. Biology of the Neonate 64 158-165.

Rodgers BD, Strack AM, Dallman MF, Hwa L \& Nicoll CS 1995 Corticosterone regulation of insulin-like growth factor I, IGF binding proteins and growth in streptozotocin-induced diabetic rats. Diabetes 44 1420-1425.

Rogler CE, Yang D, Rossetti L, Donohoe J, Alt E, Chang CJ, Rosenfeld R, Neely K \& Hintz R 1994 Altered body composition and increased frequency of diverse malignancies in insulin-like growth factor-II-transgenic mice. Journal of Biological Chemistry 269 13779-13784.

Schoenle E, Zapf J, Hauri C, Steiner T \& Froesch ER 1985 Comparison of in vivo effects of insulin-like growth factors I and II and of growth hormone in hypophysectomized rats. Acta Endocrinologica 108 167-174.

Shaar CJ, Tinsley FC, Smith MC, Clemens JA \& Neubauer BL 1989 Recombinant DNA-derived human insulin-like growth factor II (hIGF-II) stimulates growth in hypophysectomized rats. Endocrine Research 15 403-411.

Shinar DM, Endo N, Halperin D, Rodan GA \& Weinreb M 1993 Differential expression of insulin-like growth factor-I (IGF-I) and IGF-II messenger ribonucleic acid in growing rat bone. Endocrinology 132 1158-1167.

Silbermann M \& Kadar T 1977 Quantitative changes in the cellular population of the growth plate in triamcinolone-treated mice. Acta Anatomica 98 396-400.

Silbermann M, Kleinhaus U, Livne E \& Kedar T 1976 Retardation of bone growth in triamcinolone-treated mice. Journal of Anatomy 121 515-535.

Simmons DJ \& Kunin AS 1967 Autoradiographic and biochemical investigations of the effect of cortisone on the bones of the rat. Clinical Orthopedics and Related Research 551 201-215.

Smeets T \& van Buul-Offers SC 1983a A morphological study of the development of the tibial proximal epiphysis and growth plate of normal and dwarfed Snell mice. Growth 47 145-158.

Smeets T \& van Buul-Offers SC $1983 b$ The influence of growth hormone, somatomedins, prolactin and thyroxine on the morphology of the proximal tibial epiphysis and growth plate of Snell dwarf mice. Growth 47 160-173. 
Unterman TG \& Phillips LS 1985 Glucocorticoid effects on somatomedins and somatomedin inhibitors. Journal of Clinical Endocrinology and Metabolism 61 618-626.

van der Ven LTM, Roholl PJM, Reijnen-Gresnigt MG, Bloemen RJ \& van Buul-Offers SC 1997 Expression of insulin-like growth factor-II (IGF-II) and histological changes in the thymus and spleen of transgenic mice overexpressing IGF-II. Histochemistry and Cell Biology 107 193-203.

Wang E, Wang J, Chin E, Zhou J \& Bondy CA 1995 Cellular patterns of insulin-like growth factor system gene expression in murine chondrogenesis and osteogenesis. Endocrinology 136 2741-2751.

Ward A, Bates P, Fisher R, Richardson L \& Graham CF 1994 Disproportionate growth in mice with Igf-2 transgenes. Proceedings of the National Academy of Sciences of the USA 91 10365-10369.

Wergedal JE, Mohan S, Lundy M \& Baylink DJ 1990 Skeletal growth factor and other growth factors known to be present in bone matrix stimulate proliferation and protein synthesis in human bone cells. Journal of Bone and Mineral Research 5 179-186.

Wilson DM, Thomas JA, Hamm TE, Wyche J, Hintz RL \& Rosenfeld RG 1987 Transplantation of insulin-like growth factor-II-secreting tumors into nude rodents. Endocrinology 120 1896-1901.
Wolf E, Kramer R, Blum WF, Foll J \& Brem G 1994 Consequences of postnatally elevated insulin-like growth factor-II in transgenic mice: endocrine changes and effects on body and organ growth. Endocrinology 135 1877-1886.

Wolf E, Rapp K, Blum WF, Kolb H \& Brem G 1995 Skeletal growth of transgenic mice with elevated levels of circulating insulin-like growth factor-II. Growth Regulation 5 177-184.

Wolf E, Hoeflich A \& Lahm H 1998 What is the function of IGF-II in postnatal life? Answers from transgenic mouse models. Growth Hormone and IGF Research 8 185-193.

Yang H, Grahn M, Schalch DS \& Ney DM 1994 Anabolic effects of IGF-I confused with total parenteral nutrition in dexamethasonetreated rats. American Journal of Physiology, Endocrinology and Metabolism 266 E690-E698.

Zucker RM, Elstein KH, Thomas DJ \& Rogers JM 1994 Tributyltin and dexamethasone induce apoptosis in rat thymocytes by mutually antagonistic mechanisms. Toxicology and Applied Pharmacology 127 $163-170$.

Received 8 February 1999

Revised manuscript received 24 June 1999 Accepted 4 August 1999 